\title{
Calprotectin and SARS-CoV-2: A Brief-Report of the Current Literature
}

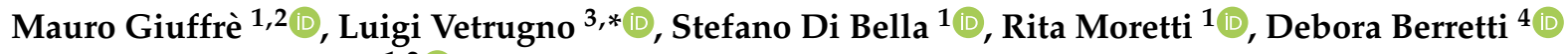 \\ and Lory Saveria Crocè ${ }^{1,2}$ D \\ 1 Department of Medical, Surgical and Health Sciences, University of Trieste, 34127 Trieste, Italy; \\ GFF.MAURO@GMAIL.COM (M.G.); stefano932@gmail.com (S.D.B.); moretti@units.it (R.M.); \\ lcroce@units.it (L.S.C.) \\ 2 Italian Liver Foundation, 34149 Trieste, Italy \\ 3 Department of Medicine, Anesthesia and Intensive Care Clinic, University of Udine, 33100 Udine, Italy \\ 4 Debora Berretti-Gastroenterology Unit, Azienda Sanitaria Universitaria Friuli Centrale, 33100 Udine, Italy; \\ debora.berretti@asufc.sanita.fvg.it \\ * Correspondence: luigi.vetrugno@asufc.sanita.fvg.it
}

Citation: Giuffrè, M.; Vetrugno, L.; Di Bella, S.; Moretti, R.; Berretti, D.; Crocè, L.S. Calprotectin and SARS-CoV-2: A Brief-Report of the Current Literature. Healthcare 2021, 9 , 956. https://doi.org/10.3390/ healthcare 9080956

Academic Editor: Antonio Taddei

Received: 12 May 2021

Accepted: 19 July 2021

Published: 29 July 2021

Publisher's Note: MDPI stays neutral with regard to jurisdictional claims in published maps and institutional affiliations.

Copyright: (C) 2021 by the authors. Licensee MDPI, Basel, Switzerland. This article is an open access article distributed under the terms and conditions of the Creative Commons Attribution (CC BY) license (https:// creativecommons.org/licenses/by/ $4.0 /)$.

\begin{abstract}
In late December 2019, a novel coronavirus (lately referred to as SARS-CoV-2) spread in the city of Wuhan, China, causing an outbreak of unusual viral pneumonia. In many people, the disease is mild and self-limiting, but in a considerable number of patients, the disease may present more severe or even fatal. Therefore, determining which patients are at higher risk of developing a more severe disease is critical. Some studies have been focused on serum and fecal calprotectin to evaluate COVID-19 disease progression and possible complications. Some assumptions can be made: (1) serum calprotectin may efficiently predict the prognosis of COVID-19 patients; (2) fecal calprotectin may appear high in COVID-19 patients due to the double hit mechanism to the intestine (inflammatory and ischemic); (3) a relationship between the complement system and neutrophil activation contributes to the procoagulant status seen in COVID-19 patients; (4) some patients may develop severe gastro-intestinal complications and fecal calprotectin can be used to monitor intestinal disease activity levels.
\end{abstract}

Keywords: fecal calprotectin; calprotectin; COVID-19; SARS-CoV-2; IBD

\section{Introduction}

In late December 2019, a novel coronavirus spread in the city of Wuhan, China, causing an outbreak of unusual viral pneumonia [1]. These patients showed symptoms of viral pneumonia, including fever, cough, and in more severe cases, dyspnea with bilateral lung infiltration requiring patients' admission to intensive care units (ICU) [1]. The cause remained unknown until 9 January 2020, when the genome sequence of the virus was sequenced and made available to the scientific community [1]. Initially referred to as 2019-nCoV and later as severe acute respiratory syndrome coronavirus 2 (SARS-CoV-2), it was branded COVID-19 by the World Health Organization (WHO) in February 2020 [2].

In many people, the disease is mild and self-limiting, but in a considerable number of patients, the disease may present more severe or even fatal. At the moment of writing this report, almost 123 million people have been infected with SARS-CoV-2, with 2.7 million deaths worldwide by COVID-19. Therefore, determining which patients are at higher risk of developing a more severe disease is critical. For example, patients with certain risk factors such as older age, diabetes, obesity, and coronary artery disease are more likely to be admitted to the hospital [3]. Moreover, several risk scores accounting for risk factors and laboratory values have been proposed and none of them have performed efficiently in predicting COVID-19 progression or have been externally validated with excellent results [4-6], which is easy to understand considering that the pathogenesis of COVID-19 
in humans has not yet been fully elucidated. Leukopenia is a common finding of peripheral blood of these patients [5]. However, tissue and organ analysis revealed a significant neutrophilic infiltrate. Enhanced neutrophil infiltration, alongside the release of neutrophil extracellular traps, is likely to contribute to the organ damage seen in COVID-19 [5]. Neutrophils' role in COVID-19 has been increasingly investigated, together with the role of surrogate markers of neutrophilic activation such as calprotectin. In fact, some studies have focused on calprotectin concentrations in serum and fecal samples of patients with COVID-19 in order to study disease progression and possible complications [7]. The aim of this narrative brief-report is to summarize the current evidence on calprotectin in COVID19. The current literature search was conducted to identify recent papers on this subject on the MEDLINE database using the following keywords: "COVID-19", "calprotectin", "S100A8/A9", "serum calprotectin", and "fecal calprotectin" from 1 December 2019 to 30 June 2021. Essentially, we evaluated studies that included patients with a minimum age of 18 years that tested positive by RT-PCR to SARS-CoV-2, whose level of serum or fecal calprotectin were measured regardless of the clinical setting.

\section{What Is Calprotectin?}

Calprotectin belongs to the family of the S- 100 proteins, first isolated from blood leukocytes in 1980 [8]. Calprotectin constitutes as much as $60 \%$ of the soluble protein content of the cytosol of neutrophils (despite being present in lower concentrations in macrophages, granulocytes, and monocytes) and is secreted during the inflammatory response. Human calprotectin is a $24 \mathrm{kDa}$ [9] dimer formed by the two protein monomers of S100-A8 (10.8 kDa) and S100-A9 (13.2 kDa). Occasionally, the two monomers can bind non-covalently to form $48 \mathrm{kDa}$ tetramers [9]. S100-A8/ A9 genes are located on chromosome 1q21 [10].

Calprotectin is a metal-binding protein with a high affinity especially to calcium but also to zinc, iron, and manganese [11]. Each monomer has calcium-binding sites and can bind two calcium ions [12]. Calcium-binding induces conformational changes that increase calprotectin affinity for other transition metals $[9,11,13]$.

Upon neutrophil activation or death, calprotectin is released to the extracellular environment, where it can exert its function. In particular, calprotectin is known to have direct bactericidal and pseudo-cytotoxic properties that arise from its active sequestration of zinc and manganese ions, which prevent its use in pathogens' metabolic and replicative processes $[9,13]$. Given its relatively small size, easy tissue-to-blood diffusion, and resistance to enzymatic degradation, calprotectin is a sensitive marker of neutrophil activation [14,15], with a reported half-life of five hours [16]. Furthermore, calprotectin is an endogenous ligand of toll-like receptor 4 (TLR-4), triggers the inflammatory response via tumor-necrosis factor $\alpha$, and is a mediator on the rapid rearrangement of the cytoskeleton, which is essential for cell migration during the immune response [17]. Calprotectin release also weakens cellular adhesion, favoring leukocyte extravasation [17].

Serum levels are usually reported below $1 \mu \mathrm{g} / \mathrm{L}$ in healthy individuals; however, serum concentration may increase by 100 times in inflammation. On the other hand, fecal calprotectin (FC) is released by neutrophils that reach the intestinal membrane during active inflammation and is then excreted in the stool [17]. It is still unclear whether or not there is a quantitative correlation between serum and fecal calprotectin [17].

\section{Serum Calprotectin and COVID-19}

As stated in the previous paragraph, calprotectin is predominantly restricted to the intracellular compartment of neutrophils, which are the most abundant human innate immune effector cells, possessing a broad variety of antimicrobial substances that are stored in specialized granules. Given that these substances can also damage host tissues, their release is strictly regulated through three major processes: phagocytosis, degranulation, and the release of neutrophil extracellular traps (NETs) [18]. NETs are large extracellular web-like structures principally composed of cytosolic and granule proteins (including calprotectin) 
that are assembled over a scaffold of decondensed chromatin. NETs are extremely efficient in trapping, neutralizing, and killing bacteria, viruses, fungi, and parasites $[18,19]$. In addition, elevated blood levels of NETs and neutrophil-derived calprotectin were associated with a higher risk of morbid thrombotic events in COVID-19 patients despite prophylactic anticoagulation $[7,20,21]$.

In addition to possible pathogenic mechanisms, serum calprotectin does not need de novo synthesis, thus offering a decisive kinetic advantage as a first sign of severe inflammation in contrast to other routinely measured serum biomarkers such as CRP or procalcitonin (PCT). For example, Silvin et al. found that patients with severe COVID19 exhibited exponentially higher blood calprotectin if compared to patients with more moderate disease or controls [22]. In addition, calprotectin concentrations correlated with neutrophil count $(\mathrm{R}=0.62, p<0.001)$, plasma fibrinogen $(\mathrm{R}=0.76, p<0.001)$ and $\mathrm{D}$-Dimer $(\mathrm{R}=0.64, p<0.001)$ [22]. Similar data were reported by Shi et al., who analyzed sera obtained from 172 patients [23]. In particular, they found that calprotectin levels were significantly higher in those individuals who required mechanical ventilation at any point during their hospitalization ( 8039 vs. $3365 \mathrm{ng} / \mathrm{mL}, p<0.001$ ) [23]. Moreover, calprotectin was found to correlate with $\mathrm{C}$-reactive protein (CRP) $(\mathrm{R}=0.44, p<0.001)$, neutrophil count $(\mathrm{R}=0.50, p<0.001)$, ferritin $(\mathrm{R}=0.31, p<0.001)$, lactate dehydrogenase $(\mathrm{R}=0.52, p<0.001)$, and platelet count $(R=0.39, p<0.001)$, and to discriminate between patients that required mechanical ventilation and those who did not, with an area under the receiver operating characteristic (AUROC) of 0.794 [23]. However, the authors did not provide calprotectin cutoffs and their respective discriminative metrics [23]. Furthermore, Cherubini et al. found that patients with SARS-CoV-2 had higher average plasma calprotectin levels $(352.3 \mathrm{ng} / \mathrm{mL})$ if compared to (1) patients with symptoms but negative nasopharyngeal PCR-testing $(177.2 \mathrm{ng} / \mathrm{mL}$ ) or (3) individuals without symptoms and negative nasopharyngeal PCRtesting $(45.3 \mathrm{ng} / \mathrm{mL})$. The authors reported that calprotectin can discriminate between symptomatic patients (COVID-positive vs. COVID-negative) with an AUROC of 0.72 and reported the cut-off 131.3 as being the most performant, with a specificity of $70.77 \%$ and a sensitivity of $69.49 \%$ [24].

Bauer et al. reported that serum calprotectin had the best discriminative ability to predict ICU admission (AUROC 0.70, 95\% C.I. 0.42-0.99) and multi-organ failure within $72 \mathrm{~h}$ (AUROC $0.87,95 \%$ C.I. 0.63-1) if compared to other commonly employed biomarkers (i.e., lactate, CRP, PCT) [25]. Comparable results were reported by Chen et al. in terms of serum calprotectin prediction of ICU admission and subsequent death [26]. In particular, the authors highlighted that patients with higher serum calprotectin had a 13-fold risk of death at 60 days from hospital admission [26]. In a recent case series of 66 patients, De Guardiana-Romualdo et al. reported that hospitalized COVID-19 patients who did not survive the infection had two-fold the median values of serum calprotectin than those who survived [27].

Current findings in terms of serum calprotectin and COVID-19 are summarized in Table 1. 


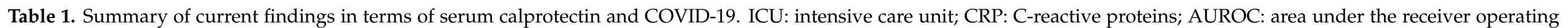
characteristic.

\begin{tabular}{|c|c|c|c|}
\hline Authors, Country & Design & Sample Size & Primary Results/Conclusions \\
\hline \multirow{3}{*}{$\begin{array}{l}\text { Chen et al. [27] } \\
\text { (July, 2020) } \\
\text { Wuhan (China) }\end{array}$} & \multirow{3}{*}{ Retrospective } & Total, $n=121$ & Mean Calprotectin Concentrations: ICU, $9220 \mathrm{ng} / \mathrm{mL}$ vs. non-ICU, $7800 \mathrm{ng} / \mathrm{mL}(p=0.0001)$. \\
\hline & & ICU, $n=40$ & \multirow{2}{*}{$\begin{array}{l}\text { Serum calprotectin can discriminate with an AUROC of } 0.86 \text { and a cut-off of } 6195 \mathrm{ng} / \mathrm{mL} \\
\text { (sensitivity } 85 \% \text {, specificity } 82.7 \% \text { ) ICU admission. Also, patients with serum } \\
\text { calprotectin }>6195 \mathrm{ng} / \mathrm{mL} \text { had a } 13 \text {-fold risk of death at } 60 \text { days from hospital admission. }\end{array}$} \\
\hline & & Non-ICU, $n=81$ & \\
\hline \multirow{4}{*}{$\begin{array}{l}\text { Shi et al. [24] } \\
\text { (July, 2020) } \\
\text { Michigan (USA) }\end{array}$} & \multirow{4}{*}{ Cohort } & Total, $n=172$ & $\begin{array}{l}\text { Mean Calprotectin Concentrations: patients who needed ventilation, } 8039 \mathrm{ng} / \mathrm{mL} \text { vs. those } \\
\text { who did not, } 3365 \mathrm{ng} / \mathrm{mL}(p<0.0001) .\end{array}$ \\
\hline & & Room air group, $n=41$ & \multirow{3}{*}{$\begin{array}{l}\text { Calprotectin levels were significantly higher in those individuals who required mechanical } \\
\text { ventilation at any point during their hospitalization. Serum calprotectin could discriminate } \\
\text { between patients that required mechanical ventilation and those who did not, with an } \\
\text { AUROC of } 0.794 \text {. }\end{array}$} \\
\hline & & $\begin{array}{l}\text { Non-invasive oxygen, } \\
\quad n=71\end{array}$ & \\
\hline & & $\begin{array}{l}\text { Invasive ventilation, } \\
\quad n=60\end{array}$ & \\
\hline \multirow{3}{*}{$\begin{array}{l}\text { De Guadiana-Romualdo et al. [28] } \\
\text { (August, 2020) } \\
\text { Cartagena (Spain) }\end{array}$} & \multirow{3}{*}{ Case Series } & Total, $n=66$ & $\begin{array}{l}\text { Mean Calprotectin Concentrations: survivors, } 3540 \mathrm{ng} / \mathrm{mL} \text { vs. non-survivors, } 7900 \mathrm{ng} / \mathrm{mL} \\
\qquad(p<0.001) .\end{array}$ \\
\hline & & Survivors, $n=8$ & \multirow{2}{*}{$\begin{array}{l}\text { Serum calprotectin positively correlated with other inflammation markers and was } \\
\text { significantly higher in non-survivors, thus highlighting a possible prognostic role in } \\
\text { COVID-19 patients. }\end{array}$} \\
\hline & & Non-Survivors, $n=58$ & \\
\hline \multirow{3}{*}{$\begin{array}{l}\text { Silvin et al. [23] } \\
\text { (August, 2020) } \\
\text { Villejuif (France) }\end{array}$} & \multirow{3}{*}{ Cohort } & Total, $n=158$ & $\begin{array}{l}\text { Mean Calprotectin Concentrations: severe, } 4983 \mathrm{ng} / \mathrm{mL} \text { vs. non-severe } 985 \mathrm{ng} / \mathrm{mL} \\
\qquad(p<0.0001) .\end{array}$ \\
\hline & & Non-Severe, $n=39$ & \multirow{2}{*}{$\begin{array}{l}\text { Patients with more severe COVID-19 exhibited exponentially higher serum calprotectin if } \\
\text { compared to patients with more moderate disease or controls. Serum calprotectin can } \\
\text { discriminate between severe and non-severe disease with an AUROC of } 0.959 \text {. }\end{array}$} \\
\hline & & Controls, $n=86$ & \\
\hline \multirow{3}{*}{$\begin{array}{l}\text { Bauer et al. [26] } \\
\text { (November, 2020) } \\
\text { Berlin, Germany }\end{array}$} & \multirow{3}{*}{ Cohort } & Total, $n=19$ & Mean Calprotectin Concentrations: ICU, 3770 ng/mL vs. non-ICU, 2080 ng/mL ( $p=0.15)$. \\
\hline & & $\mathrm{ICU}, n=8$ & \multirow{2}{*}{$\begin{array}{l}\text { Serum calprotectin had the best discriminative ability to predict ICU admission (AUROC } \\
0.70,95 \% \text { C.I. } 0.42-0.99 \text { ) and multi-organ failure within } 72 \mathrm{~h} \text { (AUROC } 0.87,95 \% \text { C.I. } 0.63-1 \text { ) } \\
\text { if compared to other commonly employed biomarkers. }\end{array}$} \\
\hline & & Non-ICU, $n=11$ & \\
\hline \multirow{4}{*}{$\begin{array}{l}\text { Cherubini et al. [25] } \\
\text { (May, 2021) } \\
\text { Rome (Italy) }\end{array}$} & \multirow{4}{*}{ Cohort } & Total, $n=195$ & $\begin{array}{l}\text { Mean Calprotectin Concentrations: hospitalized patients with positive RT-PCR, } 352.3 \mathrm{ng} / \mathrm{mL} \\
\text { vs. patients with symptoms but negative nasopharyngeal RT-PCR, } 177.2 \mathrm{ng} / \mathrm{mL} \text { vs. } \\
\text { individuals without symptoms and negative nasopharyngeal RT-PCR (45.3 ng/mL). }\end{array}$ \\
\hline & & $\begin{array}{l}\text { Hospitalized Patients with } \\
\text { positive RT-PCR, } n=65\end{array}$ & \multirow{3}{*}{$\begin{array}{l}\text { Calprotectin can discriminate between symptomatic patients (COVID-positive vs. } \\
\text { COVID-negative) with an AUROC of } 0.72 \text { and reported the cut-off } 131.3 \mathrm{ng} / \mathrm{mL} \text {, being the } \\
\text { most performant with a specificity of } 70.77 \% \text { and a sensitivity of } 69.49 \%\end{array}$} \\
\hline & & $\begin{array}{c}\text { Hospitalized Patients with } \\
\text { negative RT-PCR, } n=59\end{array}$ & \\
\hline & & $\begin{array}{l}\text { Healthy individuals screened } \\
\text { with negative RT-PCR, } n=71\end{array}$ & \\
\hline
\end{tabular}




\section{Fecal Calprotectin and COVID-19}

Previous studies indicate that SARS-CoV-2 binds to intestinal epithelial cells via specific receptors such as angiotensin-converting enzyme-2 (ACE-2) and the transmembrane serine protease-2 $[28,29]$. The virus can infect intestinal epithelial cells, promoting acute inflammation characterized by infiltration of neutrophils and macrophages, thus the hypothesis of increased fecal calprotectin as a surrogate of intestinal infection [30]. Gastrointestinal symptoms are present in up to 28\% of patients with COVID-19 [31-33] and fecal SARS-CoV-2-RNA was detected in approximately $50 \%$ of positive individuals [32-34], which persists after clearance from respiratory samples [35], with a mean fecal shedding of 17 days [36]. Current findings in terms of FC and COVID-19 are summarized in Table 2.

Table 2. Summary of current findings in terms of fecal calprotectin and COVID-19. CRP: C-reactive proteins; IL-6: interleukin-6; FC: fecal calprotectin.

\begin{tabular}{|c|c|c|c|}
\hline Authors, Country & Design & Sample Size & Primary Results/Conclusions \\
\hline \multirow{3}{*}{$\begin{array}{l}\text { Effenberger et al. [31] } \\
\quad \text { (August, 2020) } \\
\text { Innstruk (Austria) }\end{array}$} & \multirow{3}{*}{ Cohort } & Total, $n=40$ & $\begin{array}{l}\text { Mean Calprotectin Concentrations: patients with diarrhea } 80.2 \mathrm{mg} / \mathrm{kg} \text { vs. } \\
\text { patients without diarrhea } 17.3 \mathrm{mg} / \mathrm{kg} \text {. }\end{array}$ \\
\hline & & $\begin{array}{c}\text { Patients with } \\
\text { diarrhea, } n=22\end{array}$ & \multirow{2}{*}{$\begin{array}{l}\text { Patients with acute diarrhea showed higher FC level if compared to } \\
\text { patients without diarrhea. FC concentration } \\
\text { correlates with IL-6 but not to other markers of inflammation such as } \\
\text { CRP. Viral RNA was not detected in stools from patients with ongoing } \\
\text { diarrhea, and no relation was found between SARS-CoV-2 RNA and FC. }\end{array}$} \\
\hline & & $\begin{array}{l}\text { Patients } \\
\text { without } \\
\text { diarrhea, } n=18\end{array}$ & \\
\hline $\begin{array}{l}\text { Giuffrè et al. [37] } \\
\text { (August, 2020) } \\
\text { Trieste, Italy }\end{array}$ & Cohort & Total, $n=25$ & $\begin{array}{l}\text { Approximately, } 84 \% \text { of patients showed increased FC despite being } \\
\text { asymptomatic for gastrointestinal symptoms. Two patients with } \\
\text { particularly high FC developed spontaneous intestinal perforation. }\end{array}$ \\
\hline $\begin{array}{l}\text { Britton et al. [38] } \\
\text { (September, 2020) } \\
\text { New York (USA) }\end{array}$ & Retrospective & Total, $n=43$ & $\begin{array}{l}\text { SARS-CoV-2 RNA was seen in stools of } 41 \% \text { of patients, being slightly } \\
\text { more prevalent in patients with diarrhea.FC did not correlate } \\
\text { withgastrointestinal symptoms or viral level detected. }\end{array}$ \\
\hline \multirow{2}{*}{$\begin{array}{l}\text { Ojetti et al. [39] } \\
\text { (November, 2020) } \\
\text { Rome (Italy) }\end{array}$} & \multirow[b]{2}{*}{ Cohort } & \multirow[b]{2}{*}{ Total, $n=65$} & $\begin{array}{l}\text { Mean Calprotectin Concentrations: patients with radiological interstitial } \\
\text { pneumonia had higher FC if compared to patients without anomalies } \\
\text { (71.3 vs. } 11.9 \mu \mathrm{g} / \mathrm{g}, p<0.001) .\end{array}$ \\
\hline & & & $\begin{array}{l}\text { Patients with normal FC were younger ( } 33 \text { vs. } 56 \text { years old, } p=0.0024) \\
\text { and mostly men }(87 \% \text { vs. } 52.6 \%) \text {. Also, patients with elevated FC were } \\
\text { more likely to have gastrointestinal symptoms }(47.4 \% \text { vs } 15.2 \% \text {, } \\
\qquad p=0.006) .\end{array}$ \\
\hline $\begin{array}{c}\text { Zerbato et al. [38] } \\
\text { (June, 2021) } \\
\text { Trieste, Italy }\end{array}$ & Cohort & Total, $n=51$ & $\begin{array}{l}\text { The authors did not detect any differences in FC concentrations between } \\
\text { patients with and without diarrhea. However, the patients with } \\
\text { SARS-CoV-2 RNA detection in fecal samples had higher FC ( } 74 \text { vs. } \\
39 \mathrm{mg} / \mathrm{kg}, p<0.001 \text { ), lower neutrophil counts ( } 5550 \mathrm{vs.} 4390 \text { cell } / \mu \mathrm{L} \text {, } \\
\quad p<0.035) \text {, higher D-Dimer ( } 723 \text { vs. } 580 \mathrm{ng} / \mathrm{mLFEU}) .\end{array}$ \\
\hline
\end{tabular}

Effenberger et al. analyzed 40 patients with COVID-19 admitted at the University Hospital of Innsbruck (Austria) [30]. Patients with acute diarrhea showed a higher FC level if compared to patients without diarrhea (123.2 vs. $17.3 \mu \mathrm{g} / \mathrm{g}, p<0.001)$ [30]. FC concentration correlates with interleukin- 6 but not to other markers of inflammation such as CRP [31]. Notably, viral RNA was not detected in stools from patients with ongoing diarrhea, and no relation was found between SARS-CoV-2 RNA and FC [30].

Zerbato et al. enrolled 51 consecutive adults with SARS-CoV-2 pneumonia. The authors did not detect any differences in FC concentrations between patients with and without diarrhea. However, the patients with SARS-CoV-2 RNA detected in fecal samples had higher FC (74 vs. $39 \mathrm{mg} / \mathrm{kg}, p<0.001)$, lower neutrophil counts (5550 vs. 4390 cell/ $\mu \mathrm{L}$, $p<0.035$ ), and higher D-Dimer (723 vs. $580 \mathrm{ng} / \mathrm{mLFEU})$ [40]. On the contrary, Britton et al. did not find any correlation or difference in FC concentrations between patients stratified by gastrointestinal symptoms or detection of fecal viral-RNA [38]. 
Ojetti et al. conducted an observational study of 65 patients admitted to the Emergency Department of the Gemelli University Hospital (Rome, Italy) [39]. Elevated FC levels ( $>50 \mu \mathrm{g} / \mathrm{g}$ ) were found in $29.2 \%$ of patients. Among these, $57.9 \%$ showed radiological findings compatible with COVID-19, whereas only $10.9 \%$ of patients in the group with normal FC showed radiological anomalies [41]. In particular, patients with radiological interstitial pneumonia had higher FC if compared to patients without anomalies (71.3 vs. $11.9 \mu \mathrm{g} / \mathrm{g}, p<0.001$ ). In addition, patients with normal FC were younger (33 vs. 56 years old, $p=0.0024)$ and mostly men ( $87 \%$ vs. $52.6 \%)$ [41]. Also, patients with elevated FC were more likely to have gastrointestinal symptoms $(47.4 \%$ vs $15.2 \%, p=0.006)$ [41].

\section{Fecal Calprotectin and Mesenteric Ischemia in COVID-19 Patients}

According to a few studies, FC can be slightly elevated in patients with ischemic bowel disease [39,42]. Currently, thirteen cases of acute mesenteric ischemia in COVID19 patients have been reported [43]; however, FC has not been evaluated in any of the aforementioned cases.

Interestingly, Giuffrè et al. enrolled 25 consecutive patients, of which $84 \%$ showed increased FC despite being asymptomatic for gastrointestinal symptoms. The authors did not detect any significant correlation between FC and CRP. However, they found a strong positive correlation between FC and D-Dimer $(R=0.745, p<0.001)$ [37]. Besides, two patients with particularly high FC developed spontaneous intestinal perforation [37,44]. The authors hypothesized that the mechanism behind intestinal perforation was related to a thrombosis localized to the gut and that FC increase is related to virus-related inflammation and to thrombosis-induced ischemia, as showed by gross pathology [45].

\section{Conclusions}

Unfortunately, the evidence on the role of calprotectin in COVID-19 is only in its infancy. However, some assumptions can be made: (1) serum calprotectin may efficiently predict the prognosis of COVID-19 patients; (2) FC may appear high in COVID-19 patients due to the double hit mechanism to the intestine (inflammatory and ischemic); (3) a relationship between the complement system and neutrophil activation contributes to the procoagulant status seen in COVID-19 patients; (4) some patients may develop severe gastro-intestinal complications and FC can be used to monitor intestinal disease activity levels. Nevertheless, more studies are required to further define the role of calprotectin in COVID-19 patients.

Author Contributions: M.G., L.V., S.D.B., R.M., D.B. and L.S.C., performed literature research and drafted the original version of the manuscript. All authors have read and agreed to the published version of the manuscript.

Funding: This research received no external funding.

Institutional Review Board Statement: Not applicable.

Informed Consent Statement: Not applicable.

Data Availability Statement: Not applicable.

Conflicts of Interest: The authors declare no conflict of interest.

\section{References}

1. Zhu, N.; Zhang, D.; Wang, W.; Li, X.; Yang, B.; Song, J.; Zhao, X.; Huang, B.; Shi, W.; Lu, R.; et al. A Novel Coronavirus from Patients with Pneumonia in China, 2019. N. Engl. J. Med. 2020, 382, 727-733. [CrossRef]

2. Zhou, F.; Yu, T.; Du, R.; Fan, G.; Liu, Y.; Liu, Z.; Xiang, J.; Wang, Y.; Song, B.; Gu, X.; et al. Clinical course and risk factors for mortality of adult inpatients with COVID-19 in Wuhan, China: A retrospective cohort study. Lancet 2020, 395, 1054-1062. [CrossRef]

3. Sim, B.L.H.; Chidambaram, S.K.; Wong, X.C.; Pathmanathan, M.D.; Peariasamy, K.M.; Hor, C.P.; Chua, H.J.; Goh, P.P. Clinical characteristics and risk factors for severe COVID-19 infections in Malaysia: A nationwide observational study. Lancet Reg. Health-West. Pac. 2020, 4, 100055. [CrossRef] 
4. Altschul, D.J.; Unda, S.R.; Benton, J.; de la Garza Ramos, R.; Cezayirli, P.; Mehler, M.; Eskandar, E.N. A novel severity score to predict inpatient mortality in COVID-19 patients. Sci. Rep. 2020, 10, 1-8. [CrossRef] [PubMed]

5. Sambataro, G.; Giuffrè, M.; Sambataro, D.; Palermo, A.; Vignigni, G.; Cesareo, R.; Crimi, N.; Torrisi, S.E.; Vancheri, C.; Malatino, L.; et al. The Model for Early COvid-19 Recognition (MECOR) Score: A Proof-of-Concept for a Simple and LowCost Tool to Recognize a Possible Viral Etiology in Community-Acquired Pneumonia Patients during COVID-19 Outbreak. Diagnostics 2020, 10, 619. [CrossRef] [PubMed]

6. Shang, Y.; Liu, T.; Wei, Y.; Li, J.; Shao, L.; Liu, M.; Zhang, Y.; Zhao, Z.; Xu, H.; Peng, Z.; et al. Scoring systems for predicting mortality for severe patients with COVID-19. EClinicalMedicine 2020, 24, 100426. [CrossRef] [PubMed]

7. Tomar, B.; Anders, H.J.; Desai, J.; Mulay, S.R. Neutrophils and Neutrophil Extracellular Traps Drive Necroinflammation in COVID-19. Cells 2020, 9, 1383. [CrossRef] [PubMed]

8. Fagerhol, M.K.; Dale, I.; Anderson, T. Release and Quantitation of a Leucocyte Derived Protein (L1). Scand. J. Haematol. 1980, 24, 393-398. [CrossRef]

9. Brophy, M.B.; Nolan, E.M. Manganese and microbial pathogenesis: Sequestration by the mammalian immune system and utilization by microorganisms. ACS Chem. Biol. 2015, 10, 641-651. [CrossRef] [PubMed]

10. Sedaghat, F.; Notopoulos, A. S100 protein family and its application in clinical practice. Hippokratia 2008, 12, 198-204.

11. Champaiboon, C.; Sappington, K.J.; Guenther, B.D.; Ross, K.F.; Herzberg, M.C. Calprotectin S100A9 calcium-binding loops I and II are essential for keratinocyte resistance to bacterial invasion. J. Biol. Chem. 2009, 284, 7078-7090. [CrossRef] [PubMed]

12. Strupat, K.; Rogniaux, H.; Van Dorsselaer, A.; Roth, J.; Vogl, T. Calcium-induced noncovalently linked tetramers of MRP8 and MRP14 are confirmed by electrospray ionization-mass analysis. J. Am. Soc. Mass Spectrom. 2000, 11, 780-788. [CrossRef]

13. Stř́iž, I.; Trebichavský, I. Calprotectin-A pleiotropic molecule in acute and chronic inflammation. Physiol. Res. 2004, 53, 245-253.

14. Røseth, A.G.; Fagerhol, M.K.; Aadland, E.; Schjønsby, H. Assessment of the neutrophil dominating protein calprotectin in feces: A methodologic study. Scand. J. Gastroenterol. 1992, 27, 793-798. [CrossRef] [PubMed]

15. Berntzen, H.B.; Ölmez, Ü.; Fagerhol, M.K.; Munthe, E. The leukocyte protein 11 in plasma and synovial fluid from patients with rheumatoid arthritis and osteoarthritis. Scand. J. Rheumatol. 1991, 20, 74-82. [CrossRef]

16. Wang, S.; Song, R.; Wang, Z.; Jing, Z.; Wang, S.; Ma, J. S100A8/A9 in inflammation. Front. Immunol. 2018, 9, 1298. [CrossRef]

17. Kopi, T.A.; Shahrokh, S.; Mirzaei, A.; Aghdaei, H.A.; Kadijani, A.A. The role of serum calprotectin as a novel biomarker in inflammatory bowel diseases: A review study. Gastroenterol. Hepatol. Bed Bench 2019, 12, 183-189.

18. Papayannopoulos, V. Neutrophil extracellular traps in immunity and disease. Nat. Rev. Immunol. 2018, 18, 134-147. [CrossRef]

19. Yuen, J.; Pluthero, F.G.; Douda, D.N.; Riedl, M.; Cherry, A.; Ulanova, M.; Kahr, W.H.A.; Palaniyar, N.; Licht, C. NETosing neutrophils activate complement both on their own NETs and bacteria via alternative and non-alternative pathways. Front. Immunol. 2016, 7, 137. [CrossRef]

20. Ackermann, M.; Anders, H.J.; Bilyy, R.; Bowlin, G.L.; Daniel, C.; De Lorenzo, R.; Egeblad, M.; Henneck, T.; Hidalgo, A.; Hoffmann, M.; et al. Patients with COVID-19: In the dark-NETs of neutrophils. Cell Death Differ. 2021, 1-15. [CrossRef]

21. Maxwell, A.J.; Ding, J.; You, Y.; Dong, Z.; Chehade, H.; Alvero, A.; Mor, Y.; Draghici, S.; Mor, G. Identification of key signaling pathways induced by SARS-CoV2 that underlie thrombosis and vascular injury in COVID-19 patients. J. Leukoc. Biol. 2021, 109, 35-47. [CrossRef] [PubMed]

22. Silvin, A.; Chapuis, N.; Dunsmore, G.; Goubet, A.G.; Dubuisson, A.; Derosa, L.; Almire, C.; Hénon, C.; Kosmider, O.; Droin, N.; et al. Elevated Calprotectin and Abnormal Myeloid Cell Subsets Discriminate Severe from Mild COVID-19. Cell 2020, 182, 1401-1418. [CrossRef] [PubMed]

23. Shi, H.; Zuo, Y.; Yalavarthi, S.; Gockman, K.; Zuo, M.; Madison, J.A.; Blair, C.; Woodward, W.; Lezak, S.P.; Lugogo, N.L.; et al. Neutrophil calprotectin identifies severe pulmonary disease in COVID-19. J. Leukoc. Biol. 2021, 109, 67-72. [CrossRef]

24. Cherubini, F.; Cristiano, A.; Valentini, A.; Bernardini, S.; Nuccetelli, M. Circulating calprotectin as a supporting inflammatory marker in discriminating SARS-CoV-2 infection: An observational study. Inflamm. Res. 2021, 70, 687-694. [CrossRef]

25. Bauer, W.; Diehl-Wiesenecker, E.; Ulke, J.; Galtung, N.; Havelka, A.; Hegel, J.K.; Tauber, R.; Somasundaram, R.; Kappert, K. Outcome prediction by serum calprotectin in patients with COVID-19 in the emergency department. J. Infect. 2020. [CrossRef]

26. Chen, L.; Long, X.; Xu, Q.; Tan, J.; Wang, G.; Cao, Y.; Wei, J.; Luo, H.; Zhu, H.; Huang, L.; et al. Elevated serum levels of S100A8/A9 and HMGB1 at hospital admission are correlated with inferior clinical outcomes in COVID-19 patients. Cell. Mol. Immunol. 2020, 17, 992-994. [CrossRef]

27. de Guadiana Romualdo, L.G.; Mulero, M.D.R.; Olivo, M.H.; Rojas, C.R.; Arenas, V.R.; Morales, M.G.; Abellán, A.B.; ConesaZamora, P.; García-García, J.; Hernández, A.C.; et al. Circulating levels of GDF-15 and calprotectin for prediction of in-hospital mortality in COVID-19 patients: A case series. J. Infect. 2021, 82, e40-e42. [CrossRef]

28. Hoffmann, M.; Kleine-Weber, H.; Schroeder, S.; Krüger, N.; Herrler, T.; Erichsen, S.; Schiergens, T.S.; Herrler, G.; Wu, N.H.; Nitsche, A.; et al. SARS-CoV-2 Cell Entry Depends on ACE2 and TMPRSS2 and Is Blocked by a Clinically Proven Protease Inhibitor. Cell 2020, 181, 271-280.e8. [CrossRef] [PubMed]

29. Zhang, H.; Kang, Z.; Gong, H.; Xu, D.; Wang, J.; Li, Z.; Li, Z.; Cui, X.; Xiao, J.; Zhan, J.; et al. Digestive system is a potential route of COVID-19: An analysis of single-cell coexpression pattern of key proteins in viral entry process. Gut 2020, 69, 1010-1018. [CrossRef]

30. Effenberger, M.; Grabherr, F.; Mayr, L.; Schwaerzler, J.; Nairz, M.; Seifert, M.; Hilbe, R.; Seiwald, S.; Scholl-Buergi, S.; Fritsche, G.; et al. Faecal calprotectin indicates intestinal inflammation in COVID-19. Gut 2020, 69, 1543-1544. [CrossRef] 
31. Liang, W.; Feng, Z.; Rao, S.; Xiao, C.; Xue, X.; Lin, Z.; Zhang, Q.; Qi, W. Diarrhoea may be underestimated: A missing link in 2019 novel coronavirus. Gut 2020, 69, 1141-1143. [CrossRef]

32. Xiao, F.; Tang, M.; Zheng, X.; Liu, Y.; Li, X.; Shan, H. Evidence for Gastrointestinal Infection of SARS-CoV-2. Gastroenterology 2020, 158, 1831-1833.e3. [CrossRef]

33. Lin, L.; Jiang, X.; Zhang, Z.; Huang, S.; Zhang, Z.; Fang, Z.; Gu, Z.; Gao, L.; Shi, H.; Mai, L.; et al. Gastrointestinal symptoms of 95 cases with SARS-CoV-2 infection. Gut 2020, 69, 997-1001. [CrossRef] [PubMed]

34. Pan, Y.; Zhang, D.; Yang, P.; Poon, L.L.M.; Wang, Q. Viral load of SARS-CoV-2 in clinical samples. Lancet Infect. Dis. 2020, 20,411-412. [CrossRef]

35. Gupta, S.; Parker, J.; Smits, S.; Underwood, J.; Dolwani, S. Persistent viral shedding of SARS-CoV-2 in faeces-a rapid review. Color. Dis. 2020, 22, 611-620. [CrossRef] [PubMed]

36. Cheung, K.S.; Hung, I.F.N.; Chan, P.P.Y.; Lung, K.C.; Tso, E.; Liu, R.; Ng, Y.Y.; Chu, M.Y.; Chung, T.W.H.; Tam, A.R.; et al. Gastrointestinal Manifestations of SARS-CoV-2 Infection and Virus Load in Fecal Samples From a Hong Kong Cohort: Systematic Review and Meta-analysis. Gastroenterology 2020, 159, 81-95. [CrossRef] [PubMed]

37. Giuffrè, M.; Di Bella, S.; Sambataro, G.; Zerbato, V.; Cavallaro, M.; Occhipinti, A.A.; Palermo, A.; Crescenzi, A.; Monica, F.; Luzzati, R.; et al. COVID-19-Induced thrombosis in patients without gastrointestinal symptoms and elevated fecal calprotectin: Hypothesis regarding mechanism of intestinal damage associated with COVID-19. Trop. Med. Infect. Dis. 2020, 5, 147. [CrossRef] [PubMed]

38. Britton, G.J.; Chen-Liaw, A.; Cossarini, F.; Livanos, A.E.; Spindler, M.P.; Plitt, T.; Eggers, J.; Mogno, I.; Gonzalez-Reiche, A.; Siu, S.; et al. SARS-CoV-2-specific IgA and limited inflammatory cytokines are present in the stool of select patients with acute COVID-19. medRxiv 2020. [CrossRef]

39. Hsieh, J.; Brandt, L. Fecal Calprotectin in Ischemic Colitis (IC). Am. J. Gastroenterol. 2009, 104, S164. [CrossRef]

40. Zerbato, V.; Di Bella, S.; Giuffrè, M.; Jaracz, A.W.; Gobbo, Y.; Luppino, D.; Macor, P.; Segat, L.; Koncan, R.; D’Agaro, P.; et al. High fecal calprotectin levels are associated with SARS-CoV-2 intestinal shedding in COVID-19 patients: A proof-of-concept study. World J. Gastroenterol. 2021, 27, 3130-3137. [CrossRef]

41. Ojetti, V.; Saviano, A.; Covino, M.; Acampora, N.; Troiani, E.; Franceschi, F. COVID-19 and intestinal inflammation: Role of fecal calprotectin. Dig. Liver Dis. 2020, 52, 1231-1233. [CrossRef]

42. Schoepfer, A.M.; Trummler, M.; Seeholzer, P.; Criblez, D.H.; Seibold, F. Accuracy of four fecal assays in the diagnosis of colitis. Dis. Colon Rectum 2007, 50, 1697-1706. [CrossRef] [PubMed]

43. Singh, B.; Kaur, P. COVID-19 and acute mesenteric ischemia: A review of literature. Hematol. Transfus. Cell Ther. 2020, 43, 112-116. [CrossRef] [PubMed]

44. Giuffrè, M.; Bozzato, A.M.; Di Bella, S.; Occhipinti, A.A.; Martingano, P.; Cavallaro, M.F.M.; Luzzati, R.; Monica, F.; Cova, M.A.; Crocè, L.S. Spontaneous rectal perforation in a patient with SARS-CoV-2 infection. J. Pers. Med. 2020, 10, 157. [CrossRef] [PubMed]

45. Gartland, R.M.; Velmahos, G.C. Bowel Necrosis in the Setting of COVID-19. J. Gastrointest. Surg. 2020, 24, 2888-2889. [CrossRef] 